\title{
Historical Dissertations Defended in 2002
}

\section{Jolanta Karpavičienè (Vilnius University). Moters statusas Lietuvos} miestuose iki XVI a. vidurio: Vilniaus ir Kauno pavyzdys [The Status of Women in Lithuanian Cities in the Mid-Sixteenth Century: in Vilnius and Kaunas.

In her study, the author divides her topic into two main parts. In the first she concentrates on the status of town- and city women in public urban life and analyses their legal status (the problem of legal representation, legal activity, and the guardianship aspect of urban law) and the forms of women's economic activities (property relationships, economic activities). In the second part of the work she talks about the situation of women in the family. In order to discover this, the author uses the usual principle of women's in studies: she illuminates the situation of women by looking at the phases of familial life: daughter, wife, and widow. Here she talks about the creation of marriages, the right of inheritance, the gerade problem, and the property relationships of spouses. The research material allows the author in the end to draw the broader conclusion that due to the growth of the prerogatives of the Vilnius and Kaunas localgovernment institutions during the period under discussion it is possible to speak about the relatively real functioning of urban rights, which urban residents considered a guarantee of safer communal life.

Rūstis Kamuntavičius (Vytautas Magnus University, Kaunas). Lietuvos ¿vaizdžio stereotipai italu ir prancūzu XVI-XVII a. literatūroje [Lithuanian Stereotypes in Italian and French Literature of the Sixteenth and Seventeenth Centuries].

By stressing that the Italians and the French created a considerable number of texts about Lithuania and Poland and after selecting the descriptions of Lithuania by these authors as the principle source of his work, the author tries to ascertain how the stereotypes of Lithuanian cultural and political life and of the mentality of the inhabitants emerged, developed, and spread in Europe, the forms in which they are revealed in the literature of these countries as well as in what ways and why they changed. In this way, he seeks to reveal a broader problem, i.e. how European nations perceived one after another and why stereotypes, which made it harder 
for them to understand one another, developed. The author notes that the knowledge of Europeans about Lithuania was frequently fairly far from the truth even though it was spread by people who had visited Lithuania: diplomats, papal nuncios, and envoys. Most information concerned travelling conditions, political life, and the local inhabitants. The inadequacies of the value system, language, symbols influenced the birth of the stereotypes and their long life.

Vaida Kamuntavičienè (Vytautas Magnus University, Kaunas). Kataliku bažnyčios ir valstybès santykiai LDK XVII a. antrojoje pusèje [The Relationship of the Catholic Church and the State in the GDL in the Second Half of the Seventeenth Century].

After selecting for her research that period of the relationship of the Catholic Church and the state that is the least investigated by Lithuanian historians, the author seeks to investigate the dependency of the Catholic Church on the state, how the hierarchy of the Catholic Church performed duties in state and estate institutions and handled the defence of the state, as well as how a network of parish almshouses and schools was created. At the same time she analyses how the state institutions: the ruler, Parliament (Sejm), senators, and citizens handled the matters of the Catholic Church.

Audrius Abromaitis (Vilnius University). Lenkija ir Lietuvos visuomene: požiūriai i Lenkija Lietuvoje 1918-1940 m [Poland and Lithuanian Society: Views of Poland Held in Lithuania During 1918-1940].

In studying the attitudes of Lithuanian society towards Poland, the author seeks to reveal the reasons for and the circumstances surrounding the establishment of anti-Polish attitudes; to reveal changes in this point of view, connecting it with the change in Lithuania's international situation, the foreign policy objectives, and domestic political life. Although the decisive role shaping the anti-Polish attitudes was played by the occupation of the Vilnius region, the land question and perception of a Polish threat to Lithuanian national identity were also important. Therefore the opposition to Poland became an important factor influencing Lithuanian foreign policy. Nevertheless, the author notes that essential changes occurred in the 1920s, with the receding of the hope of recovering Vilnius, especially with the victories achieved during the years of independence and the rise of the German threat, all of which forced a re-evaluation of Lithuanian attitudes in respect to Poland and gradually changed the estimations in Lithuania of the neighbouring country. 
Dangiras Mačiulis (Lithuanian Institute of History, Vilnius). Lietuvos valstybès kultūros politika 1927-1940 metais [Lithuanian State Cultural Policy during 1927-1940].

The author analyses the cultural policy of the authoritarian regime of A. Smetona, not only its theoretical-ideological construction but also its practical forms: its regulating and controlling activities, the functioning of the public authorities, and the search for their methods and measures. He shows that the activities of the Ministry of Education lacked ideological direction that supported the authoritative regime and the bureaucratic apparatus was hesitant to decide an aim for the ideological content. The state was the only real supporter of culture not only in maintaining the official cultural institutions but also in attempting to support organisations uniting artists. The author pays a great deal of attention to the establishment of the Cultural Fund, the search for an original national culture, the Naujoji Romuva journal programme for the modernisation of the national culture, and the possibility for creative freedom under the conditions of an authoritative regime.

Nerijus Šepetys (Vilnius University). Molotovo-Ribentropo paktas ir Lietuva: teorinés, istoriografinès ir istorines problemos [The Molotov-Ribbentrop Pact and Lithuania: Theoretical, Historiographical, and Historical Problems].

The author stresses that in investigating the selected topic he oriented himself not to the objective reconstruction or conscious construction of the past according to the selected model but to the interpretation of historical problems that are important to historical consciousness and raised in historical scholarship. The first part of the work is devoted to defining and investigating the historical context of the principal form of the functioning of the Pact in Lithuanian historical consciousness. In the second part the significance of the Pact is raised in considering questions of the reasons for the Second World War and in considering the problem of the political motives and benefits of the USSR in signing the Pact. A phenomenological investigation of the Pact as a historical event is presented in the third part while in the fourth he seeks to prove the invalidity of the conception of the Realpolitik by Kazys Škirpa (which was oriented towards Germany), which the latter set forth in his study, Lietuvos Nepriklausomybes sutemos: 1938-1940 [Twilight of Lithuanian Independence: 1938-1940]. 
Kastytis Antanaitis (Vytautas Magnus University, Kaunas). Sovietine Lietuvos, Latvijos ir Estijos nomenklatūra (1953-1990 m.): désningumai ir ypatumai [The Nomenclature of Soviet Lithuania, Latvia, and Estonia, 1953-1990: Consistency and Special Characteristics].

This dissertation focuses not only on the political dynamics in the defined region and time but also the internal social and cultural variations of the nomenclature. The author also discusses how the totalitarian Soviet state administration system functioned, which was permeated by specific and covert party control, which functioned as a system for the constant appointment and control of the highest public officials, i.e. as a nomenclature. In separate subchapters the author expands the selected topic and discusses the establishment of the authority of the nomenclatures of the republics; the relationships of these nomenclatures with the centre of the USSR; the development of the nomenclature system in the Baltic States as well as its relationships with the party and state organs as well as the classes of society; and the cultural features of the nomenclature. At the end, he notes that the nomenclature was a separate societal and cultural group, which was distinguished by its characteristic mentality, even formed a tradition of everyday peculiar behaviour to it, and was influenced by the existence juridically established exceptions and privileges.

Vitalija Stravinskienė (Lithuanian Institute of History, Vilnius). Lenkijos lietuviu bendruomene 1944-2000 m. [Poland's Lithuanian Community 1944-2000].

The aim of the dissertation is to present a full investigation of the political, social, cultural, and national situation of the Lithuanians living in Poland in the middle and second half of the twentieth century, showing the policy of the Polish United Workers Party (PZRP) and its effect on the community's as well as showing the essential political changes that occurred during the post-communist period. The author investigates the special features of the formation of Poland's Lithuanian community and accents that from an economical-social perspective the situation of Poland's Lithuanians was determined by the government's agrarian policy. A great deal of attention is paid to the community's cultural activities: the publication of the newspaper Aušra, the creation of a network of Lithuanian schools, the activities of other Lithuanian institutions, noting that all these activities were controlled by the Polish government in enforcing communist ideology. He also asserts that, after the fall of the communist regime, possibilities to nurture the culture of the national minorities emerged but the reform of the education system and the reduction of state support to national communities had negative consequences on the activities of Poland's Lithuanians. 